\title{
Assessment of Effluents from Associated Match Industries with Emphasis on Bioaccumulation of Heavy Metals in Crab
}

\author{
Albert Achudume ${ }^{1}$, Samson Odoh ${ }^{1}$, Funso Adeniyi ${ }^{2}$ \\ ${ }^{1}$ Institute of Ecology and Environmental Studies, Obafemi Awolowo University, Ile-Ife, Nigeria \\ ${ }^{2}$ Department of Zoology, Obafemi Awolowo University, Ile-Ife, Nigeria \\ E-mail: \{aachudum, uodoh, fadeniyi\}@yahoo.com
}

Received February 15, 2010; revised March 15, 2010; accepted March 30, 2010

\begin{abstract}
Heavy metals disposed through anthropogenic activities find their way into aquatic environment through factory effluents. These heavy metals resuspend back into the water column along with the sediments and are known to affect aquatic bioresources. Effluent water samples and crabs were collected along top camp stream to evaluate heavy metal concentrations and were assessed to determine the uptake of heavy metals in crabs. Results show fluctuation in acidity/alkalinity of water samples. BOD, COD, DO, conductivity and organic phosphorous were below permissible limit, and metal concentrations (As, $\mathrm{Cu}, \mathrm{Cr}$ and $\mathrm{Zn}$ ) in water samples do not constitute a risk factor for human health. However, concentrations of Cupper ( $\mathrm{Cu})$, Iron $(\mathrm{Fe})$, Asenate (As) and Manganese (Mn) in crabs were significantly higher than the level found in the effluent water. Heavy metal poisoning has been identified among people that depend on crabs for their protein. Such effects are viewed by international health organization as attenuation of human health. The toxic elements (As, $\mathrm{Cu}, \mathrm{Fe}$ and $\mathrm{Mn}$ ) in the effluent and dissolved solid concentrations including potassium and calcium carbonate may be reduced through resource recovery.
\end{abstract}

Keywords: Heavy Metals, Aquatic Environment, Anthropogenic Activity, Aquatic Bioresource

\section{Introduction}

Effluent discharges from industries constitute a serious environmental threat to water quality and aquatic resources; including biodiversity. Likewise, contaminations of soil by the release of heavy metals as a result of industrial and anthropogenic activities are threat to human health and ecosystem [1,2]. Heavy metals are stable and recalcitrant contaminants of aquatic environments. Some metals ions are required for metabolic activity while, many inadvertently may have concentrations that lie in the narrow range between their essentiality and toxicity. Additionally, others may exhibit extreme toxicity even at low levels under certain conditions $[3,4]$. As distinct from organic substances, they migrate and accumulate in different components of natural ecosystems (water, soil, bottom deposits and aquatic animals). Most heavy metals are supposed to accumulate in aquatic animals and pass their toxic effects onto the upper links of the trophic chain, including human beings [5]. Conse- quently, regular monitoring of sensitive aquatic environments is quite necessary.

The study of organisms as pollutant monitors has several advantages over the chemical analysis of abiotic comportments. Chemical, toxicological and ecological approaches have been employed extensively in assessing impacts of heavy metal pollution in aquatic environments. Many such studies have concentrated on birds [6], Fish [5,7] in mussels [8] in other invertebrates [9] and vegetation [10].

The tendency of heavy metals to accumulate in aquatic organisms is of scientific interest not only in heavy metal chemistry but also in environmental studies. In particular, the bioavailability of tissue metal levels in crab; an important staple part of food delicacies in some localities, is an indicator of environmental pollution. Ultimately, the contents and properties of effluents could be responsible for possible environmental impact on different matrices (water column, sediment and biota), and possibly contribute to the characteristics of the receiving water.

The aim of this study was to contribute to environ- 
mental effect assessment of effluent discharged by Associated Match industry located in Southwest, Nigeria. In particular we report preliminary results regarding heavy metal concentrations in crab, as a bioindicator of heavy metal biomagnifications.

\section{Materials and Methods}

The study area was along the Eleyele industrial layout of Ibadan, North-West Local Government, Oyo State. (Figure 1). The city lies between latitudes $07^{\circ} 22^{\prime} 30^{\prime} \mathrm{N}$ and $07^{\circ} 25^{\prime} 50^{\prime \prime}$ and longitude $003^{\circ} 2^{\prime} 00^{\prime \prime} \mathrm{E}$ to $003^{\circ} 55^{\prime} 50^{\prime \prime} \mathrm{E}$, at an altitude approximately $1500 \mathrm{~m}$ above sea level. The climate of the area is influenced by Tropical Maritime (mT) and Tropical Continental (cT) air masses. The mean annual rainfall is $1413 \mathrm{~mm}$, while the mean annual temperature ranges from $22.5^{\circ} \mathrm{C}$ to $31.4^{\circ} \mathrm{C}$. The soil in the area support tropical rainforest vegetation while Kaolinite is the main clay mineral present [11-13]. The area is located in the lowland rainforest vegetation zone of Nigeria [14]. It is a major industrial section and various untreated or minimally treated wastes are discharged into the stream.

It encompasses the stretch between ten sampling sta- tions. Four of these sampling stations were established along the effluent stream ( $\mathrm{P} 5_{0}, \mathrm{P}_{1}, \mathrm{PS}_{2}$ and $\left.\mathrm{P} 5_{3}\right)$ from the industry. One station was at the confluence of the effluent stream, and adjacent natural stream (Topcamp stream, $C_{1}$ ), three stations were along the TopCamp stream $\left(\mathrm{BC}_{0}, \mathrm{BC}_{1}\right.$ and $\left.\mathrm{BC}_{2}\right)$ before the confluence $\mathrm{C}_{1}$, and the other two stations after the confluence $\left(\mathrm{AC}_{1}\right.$ and $A C_{2}$ ). A portable Global Position System (GPS) set was used to locate the grid coordinates of sampling stations.

Water samples were drawn from each of these locations mentioned above $20 \mathrm{~m}$ apart except $\mathrm{C}_{1}$ (Topcamp stream) because of its topography beneath rock and the surrounding wetland. The samples were analyzed for $\mathrm{pH}$, electrical conductivity, turbidity, total acidity and alkalinity, oxygen demand (BOD and COD) including major ions $\left(\mathrm{Cl}^{-}, \mathrm{SO}^{2-}{ }_{4}, \mathrm{~K}^{+}, \mathrm{Na}^{+}, \mathrm{Ca}^{2+}\right)$. Water samples were filtered through a $0.45 \mathrm{~mm}$ whatman no 1 filter paper. Water samples $(100 \mathrm{ml})$ were acidized to a final concentration of $2 \%$ with nitric acid. Two samples were divided into two and portion of each half was spiked with known concentrations $(0,2.5,5.0$ and $10.0 \mathrm{ppm})$ of the six analytes in order to determine percent recovery. Unspiked samples, blanks and spiked samples were analyzed by Alpha 4 atomic absorption spectrophotometer (AAS).

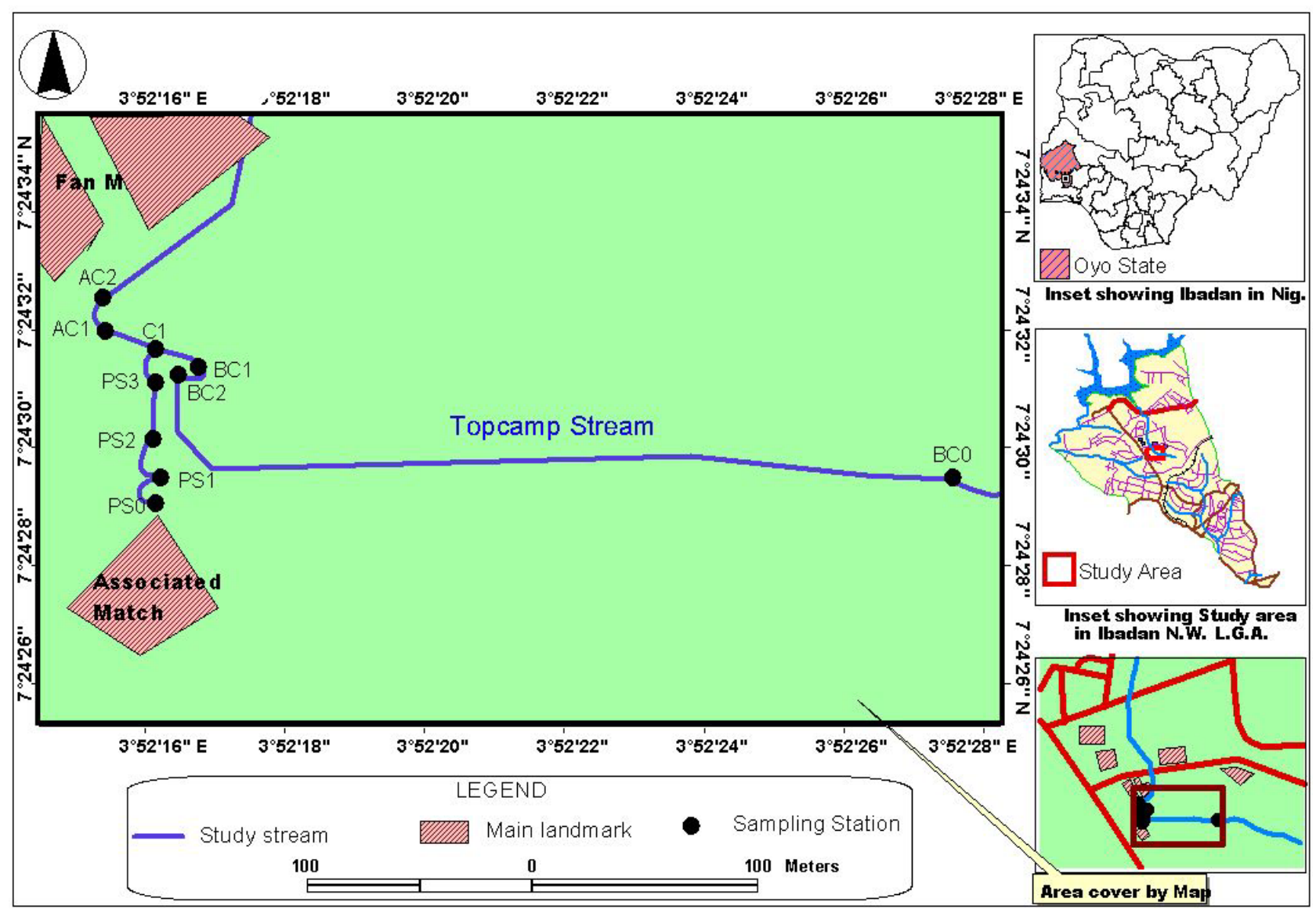

Figure 1. Detailed map of study area showing sampling stations. 
The AAS was standardized regularly once after analyzing three samples with matrix-matched standards (Inorganic Ventures, Lakewood, NJ). Standardization was verified with appropriate external standards (Spex Industries Inc., Edison, NJ). Analyte recovery in spiked samples ranged from $92-100 \%$.

At least 20 crabs Sudanenautes africanus africanus samples were collected along the Topcamp stream flow. Each crab was excised. The whole internal organs of the crab were removed by steel pliers and the damp weight was measured. All samples were kept at $85^{\circ} \mathrm{C}$ for $48 \mathrm{~h}$ to dry to constant weight. The samples were digested according to the procedure given by US EPA 1996 [15] using concentrated $\mathrm{H}_{2} \mathrm{SO}_{4}$ and $\mathrm{HNO}_{3}$ in beakers placed on a hot plate (1:10). The amount of various essential and non-essential elements like $\mathrm{As}, \mathrm{Cr}, \mathrm{Cu}, \mathrm{Fe}, \mathrm{Mn}$ and $\mathrm{Zn}$ in crab samples was determined by multiplying by the dilution factor given in $\mathrm{ppm} / \mathrm{g}$. The detection limits were as follows: $1 \mathrm{mg} / \mathrm{L}$ for Fe; $0.01 \mathrm{mg} / \mathrm{L}$ for $\mathrm{Cu}, \mathrm{As}, \mathrm{Cr}, \mathrm{Mn}$ and Zn.

Statistical analysis: Data were subjected to Barlett's test for homogeneity, followed by analysis of variance (ANOVA). For post hoc comparison Student Newman Keul's test was employed.

\section{Results and Discussion}

The present study aims in understanding the bioaccumulation patterns and demonstrates the safety of aquatic food as a supplementary source of protein in diet. The results of the physcio-chemical characteristics of the discharged effluents in water course, confluence and quality of ensuring water are summarized in Table 1. The $\mathrm{pH}$ of the effluent water fluctuated between acidic to slightly alkaline. The temperature of the surface water

Table 1. Physico-chemical characteristics of water quality at various sampling points.

\begin{tabular}{|c|c|c|c|c|c|c|c|c|c|c|}
\hline Parameter & $\mathrm{P}_{5}$ & $\mathrm{P}_{1}$ & $\mathrm{P}_{2}$ & $\mathrm{P}_{3}$ & $\mathrm{C}_{1}$ & $\mathrm{AC}_{1}$ & $\mathrm{AC}_{2}$ & $\mathrm{BC}_{\mathrm{o}}$ & $\mathrm{BC}_{1}$ & $\mathrm{BC}_{2}$ \\
\hline $\mathrm{pH}$ & 6.49 & 6.43 & 6.65 & 6.47 & 7.76 & 8.06 & 8.01 & 7.65 & 8.27 & 8.09 \\
\hline Temperature Air & 30 & 30 & 30 & 29 & 29 & 29 & 29 & 29 & 28 & 30 \\
\hline temp. $\left({ }^{\circ} \mathrm{C}\right)$ & 0.4 & 0.8 & 0.8 & 1.6 & 4.4 & 4.4 & 2.3 & 3.6 & 2.4 & 2.0 \\
\hline BOD & 5.21 & 5.07 & 4.14 & 5.29 & 2.37 & 3.83 & 2.98 & 1.47 & 2.06 & 2.87 \\
\hline COD & 7780 & 2540 & 3140 & 3680 & 1120 & 840 & 780 & 280 & 680 & 480 \\
\hline Total Solid & 668 & 620 & 180 & 640 & 420 & 160 & 240 & 160 & 140 & 60 \\
\hline TSS & 9.32 & 3.26 & 4.35 & 4.70 & 1.51 & 1.13 & 0.94 & 0.064 & 0.65 & 0.67 \\
\hline Conductivity & 298.47 & 198.48 & 177.27 & 153.03 & 43.95 & 13.65 & 16.68 & 13.65 & 98.49 & 1.53 \\
\hline Turbidity & 2.6 & 2.0 & 2.4 & 3.2 & 4.8 & 4.8 & 3.8 & 4.4 & 5.2 & 3.2 \\
\hline Dissolved & 55.17 & 17.40 & 21.39 & 19.88 & 07.46 & 22.86 & 32.31 & 3.48 & 08.45 & 6.46 \\
\hline Chloride & 247.3 & 205 & 24.24 & 43.91 & 30.51 & 41.63 & 27.38 & 0.24 & 19.96 & 33.65 \\
\hline Sulphate & 0.418 & 0.458 & 0.300 & 0.305 & 0.516 & 0.592 & 0.658 & 0.120 & 0.556 & 0.760 \\
\hline Inorganic $\mathrm{PO}_{4}$ & 1.150 & 490 & 710 & 675 & 205 & 130 & 125 & 1.75 & 95 & 40 \\
\hline $\mathrm{K}^{+}$ & 34 & 30 & 36 & 40 & 30 & 28 & 24 & 08 & 08 & 1.8 \\
\hline $\mathrm{Ca}^{2+}$ & 41 & 25 & 29 & 28 & 16 & 11 & 17 & 2.6 & 8.25 & 9.6 \\
\hline $\mathrm{Na}^{+}$ & 45.82 & 51.43 & 58.03 & 47.13 & 48.57 & 44.77 & 43.88 & 1.93 & 35.90 & 42.14 \\
\hline $\mathrm{Mg}^{2+}$ & 73.9 & 69.8 & 78.35 & 65.5 & 53.55 & 51.09 & 28.54 & 24.43 & 48.73 & 37.75 \\
\hline $\mathrm{NO}_{3}^{-}$ & 720 & 260 & 540 & 540 & 150 & 70 & 60 & 30 & 50 & 40 \\
\hline $\mathrm{CaCO}_{3}$ & & & & & & & & & & \\
\hline
\end{tabular}

All the values are in $\mathrm{mgL}^{1}$ except $\mathrm{pH}$ and Electrical conductivity $(\mu \mathrm{S} / \mathrm{cm})$ and phosphate $\left(\mu \mathrm{gL}^{1}\right)$; BOD-Biological Oxygen Demand; COD-Chemical oxygen Demand; TSS-Total suspended solid. 
was near constant. However, BOD, COD, conductivity, dissolved oxygen and organic phosphorus were below WHO permissible limit [16]. On the contrary, total solid, turbidity, potassium, nitrate, chloride and calcium levels were markedly high at point source. For example, an electrical conductivity of up to $932 \mu \mathrm{s} / \mathrm{cm}$ has no effects, but water with a high salinity can be toxic to most plants and may pose salinity hazard [17]. Additionally high sodium levels contribute to salinity problems and interfer with magnesium and calcium availability resulting in sodium hazard. $\mathrm{CaCo}_{3}$ representing alkanity of water is more significant than its $\mathrm{pH}$ because it takes into account the principal constituency that influence the water's ability to regulate the $\mathrm{pH}$ of the water, thus higher $\mathrm{CaCo}_{3}$ results in lower $\mathrm{pH}$ and lower $\mathrm{CaCo}_{3}$ results in higher $\mathrm{pH}$ (Table 1).

The common African crab is one of the few species found all year round. Heavy metals absorbed by the crabs have a possibility to get accumulated in different parts of the body and the residual amount can build up to a toxic level as is the case with $\mathrm{Cu}, \mathrm{Fe}$, and $\mathrm{Mn}$. The concentration patterns in the water effluent revealed the following order $\mathrm{Mn}>\mathrm{Fe}>\mathrm{Cu}>\mathrm{Cr}>\mathrm{Zn}>\mathrm{As}$ (Figure 2) whereas the accumulation of heavy metals in crabs followed different sequence of $\mathrm{Ca}>\mathrm{Fe}>\mathrm{Mn}>\mathrm{Cu}>\mathrm{As}>$ $\mathrm{Cr}>\mathrm{Zn}$ (Figure 3). The order of accumulation in crab is proportional to various metal deposits in the effluent. The concentrations of heavy metals in unimpacted (upstream) sections of Topcamp are illustrated in Figure 4. The crabs, hepatopancreas showed higher concentration of all metals, especially, calcium this condition might be due to the fact that hepatopancreas plays a prime role in binding the metals and act as primary route of excretion.

The water analysis of heavy metals in the study area was compared to the accumulating pattern in hepato pancreas of indigenous crab, Sudanenautes africanus africanus (Figure 2). Metal concentration of arsenic, chromium, copper and zinc in water samples in this study do not constitute a risk factor for human health and appear to be below the permissible limits set by the UNEP (1993) [18]. However, metal concentration of $\mathrm{Cu}$,

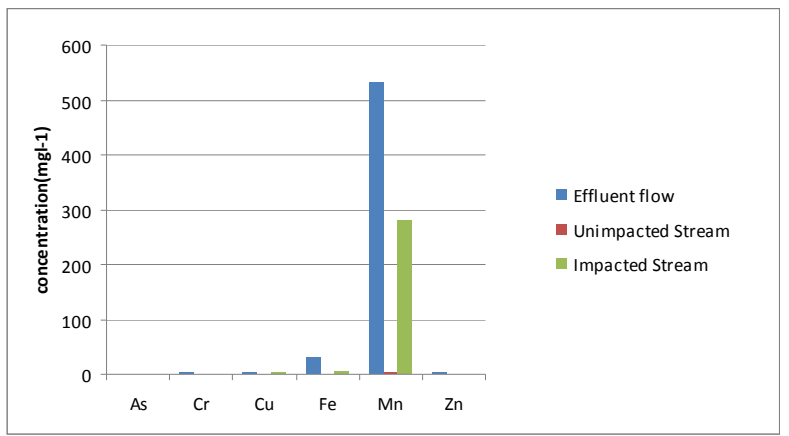

Figure 2. Mean concentration of heavy metal content of water/effluent sample $\left(\mathrm{mgl}^{-1}\right)$.

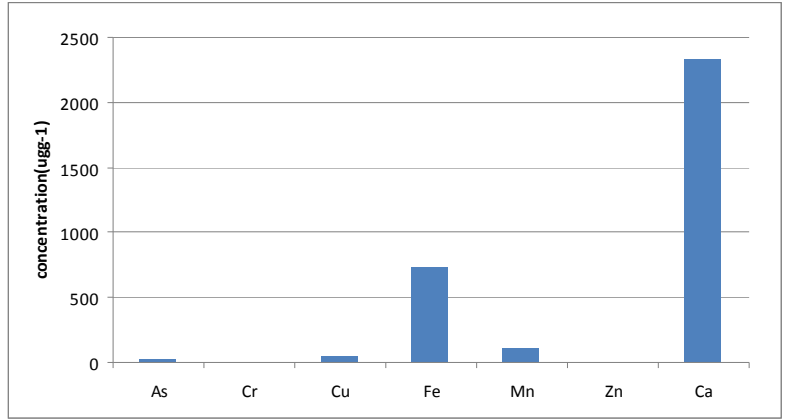

Figure 3. Mean concentration of heavy metals in crab specimen $\left(\mathrm{ugg}^{-1}\right)$ from impacted section of Topcamp Stream.

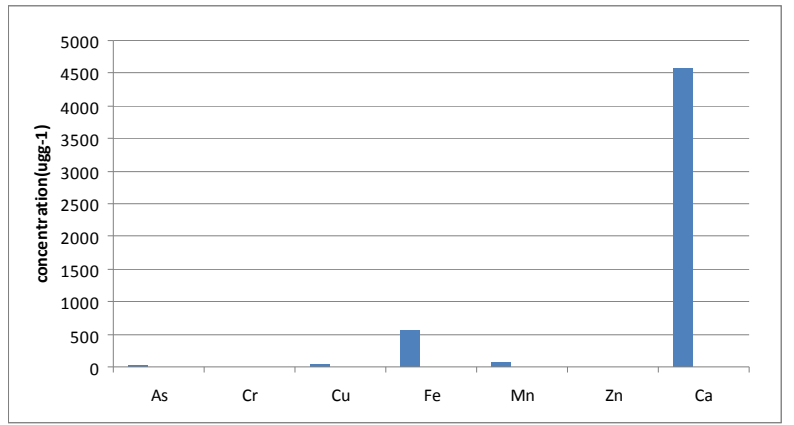

Figure 4. Mean concentration of heavy metals in crab specimens $\left(\mathrm{ugg}^{-1}\right)$ from unimpacted section of Topcamp Stream.

Fe and Mn in crabs is significantly higher than the levels found in the effluent water. Consequently, in terms of ecological, crab is irreplaceable bioindicators of the degree of damage to the water environment. Moreover, it is also important to monitor the contamination of crab with heavy metals, because frequent consumption of the contaminated crab presents a very serious health risk. The results of the present study enabled us to determine the background concentrations of these metals in both water and crab. These data will constitute a reference to future studies on the evolution of contamination in this area. On the other hand, a potential danger may occur in the future depending on the agricultural, recreational activities and effluents from the Associated Match Industries.

The crab, sudanenautes africanus africanus is economically important and forms a large part of aquatic catch in the area of study. However, heavy metal poisoning had been identified among people that depend on crabs for their protein [19]. The effects of heavy metal contamination are viewed as an international problem because of the effects on human health and ecosystem $[20,21]$. The concentrations of most toxic elements, other than $\mathrm{As}, \mathrm{Fe}, \mathrm{Cu}$ and $\mathrm{Mn}$ are not dramatically excessive. These heavy metals, the high dissolved solids concentration, including potassium and calcium carbonate may as well be withheld for corrective treatment before release 
into the aquatic environment.

\section{References}

[1] S. N. Pandey, "Accumulation of Heavy Metalss (Cd, Cr, $\mathrm{Cu}, \mathrm{Ni}$ and $\mathrm{Zn}$ ) in Raphanus Sativcrs L. and Spinacia Oleracea L. Plants Irrigated with Industrial Effluent,” Journal Environmental Biology, Vol. 27, No. 1, January 2006, pp. 381-384.

[2] P. Malaviya, U. Laikuan and V. S. Rathore, "Seasonal Variations in Different Physico-Chemical Parameters of the Effluents of Century Pulp and Paper Mill,” Journal Environmental Biology, Vol. 28, No. 2, April 2007, pp. 219-224.

[3] A. Farkas, J. Salanki and L. Varanka, "Heavy Metal Concentrations in Fish of Lake Balaton," Lakes \& Reserviors: Research and Management, Vol. 5, No. 3, 2000, pp 271279.

[4] T. Cohen, S. Hee and R. Ambrose, "Trace Metals in Fish and Invertebrate of Three California Coastal Wetlands," Marine Pollution Bulletin, Vol. 42, No. 2, 2001, pp. 232242.

[5] S. Yigit and A. Altindag, "Concentration of Heavy Metals in the Food Web of Lake Egirdir, Turkey,” Journal Environmental Biology, Vol. 27, No. 1, 2006, pp 475478.

[6] U. Perkas and Z. Ayas, "Birds of Nallihan Bird Paradise (Central Anatolia Turkey),” Turkey Journal of Zoology, Vol. 29, No. 2, 2005, pp. 45-59.

[7] A. B. Yilmaz, "Comparison of Heavy Metal Levels of Grey Mullet (Mugil Cephalus L.) and Sea Bream (Sparus Aurata L.) Caught in Iskenderum Bay (Turkey),” Turkish Journal of Veterinary Animal Science, Vol. 29, No. 2, 2005, pp. 257-262.

[8] E. Yarsan, A. Bilgili and Y. Turel, "Heavy Metal Levels in Mussels (Unio Steventanus Krynicki) Obtained from Van Lake," Turkish Journal of Veterinary Animal Science, Vol. 24, No. 4, 2000, pp. 93-96.

[9] M. L. Reddy, J. S. Reif, A. Bachand and S. H. Ridgway, "Opporutnities for Using Navy, Marine Mammals to Explore Associations between Organochlorine Contaminants and Unfavourable Effects on Reproduction," Science of Total Environment, Vol. 274, No. 3, 2001, pp. 171-182.

[10] H. G. Ozdilek, P. P. Mathisen and D. Pellegrino, "Distribution of Heavy Metals in Vegetation Surrounding the Blackstone River, USA: Considerations Regarding Sedi- ment Contamination and Long-Term Metals Transport in Freshwater Riverine Ecosystems,” Journal Environmental Biology, Vol. 28, No. 2, February 2007, pp. 493-502

[11] C. O. Nwuche and E. O. Ugoji, "Effects of Heavy Metal Pollution on the Soil Microbial Activity," International Journal of Environmental Science and Technology, Vol. 5, No. 1, February 2008, pp. 409-414.

[12] S. A. Adesoji and A. J. Farinde, "Factors Associated with the Productivity of Arable Crop Farmers in Osun State Nigeria," International Journal of Biology and Physical Sciences, Vol. 8, No. 3, 2004, pp. 57-62.

[13] A. T. Salami, M. A. Jimoh and J. I. Muoghalu, "Impact of Gold Mining on Vegetation and Soil in Southwestern Nigeria," International Journal of Environmental Studies, Vol. 60, No. 4, April 2003, pp. 343-352.

[14] R. W. J. Keay, “An Outline of Nigeria Vegetation,” 3rd Edition, Federal Government Printer, Lagos, 1959.

[15] L. Manfra, G. Moltedo, C. Virno Lamberti, C. Maggi, M. G. Finoia, S. Giuliani, F. Onorati, M. Gabellini, R. Di Mento and A. M. Cicero, "Metal Content and Toxicity of Produced Formation water (PFW): Study of the Possible Effects of the Discharge on Marine Environment," Archives of Environmental Contamination and Toxicology, Vol. 53, No. 4, November 2007, pp. 183-190.

[16] World Health Organization, "Guidelines of Dringing Water Quality in Health Criteria and Other Supporting Information,”Vol. 2, No. 2, 1984, pp. 336-347.

[17] R. S. Ayers and D. W. Westcot, "Water Quality for Agriculture, FAO Irrigation and Drainage,” Food and Agriculture Organization of the United Nations, Vol. 29, No. 1, Rome, 1985.

[18] United Nations Environment Programme, "Guidelines for Monitoring Chemical Contaminants in the Sea Using Marine Organisms. Reference Methods for Marine Pollution Studies,” Athens, Vol. 6, No. 2, 1993.

[19] E. Peri and G. P. Zauke, "Trace Metals in Crustaceans in the Antarctic Oceans," Arctic Monitoring and Assessment Programme, Vol. 10, No. 8, September 1993, pp. 527531.

[20] Z. Ayas, G. Ekmekai, S. V. Yerli and M. Ozmen, "Heavy Metal Accumulation in Water, Sediments and Fishes of Nallihan Bird Paradise," Turkey Journal of Environmental Biology, Vol. 28, No. 2, March 2007, pp. 545-549.

[21] US Environmental Protection Agency (USEPA), Method 3050B. EPA 660 13-75-009, Acid Digestion of Sediments, Sludges and Soils, Washington, D.C., 1996. 